\title{
Research on Asphalt Concrete Pavement Construction Technology for Long Span Steel Bridge Deck
}

\author{
Zhengpu Yang ${ }^{1 * *}$ \\ ${ }^{1}$ School of Highway, Chang'an University, Xi'an, Shaanxi, 710029, China
}

\begin{abstract}
Steel bridge has the advantages of large span capacity, fast installation speed, easy transportation, easy repair and replacement, and has been widely used in practical engineering. The bridge deck pavement of the steel bridge is a crucial link in the whole building and cannot be ignored. For the long span steel bridge, the bridge deck generally has the phenomenon of fatigue cracking, and the service life is difficult to reach the expected life. Laying a multi-layered protective layer structure on the orthotropic steel bridge deck can not only protect the steel bridge deck, but also increase the service life of the bridge. It also provides support and guarantee for the safety and comfort of the bridge. In addition, it effectively reduces vibration and noise caused by driving. Firstly, the advantages and disadvantages of the three types of steel bridge deck pavement technology commonly used in China are discussed in this paper, the merits of different deck paving techniques are pointed out. Then, the construction technology of the lower cast type + SMA pavement structure is analyzed in combination with a steel bridge deck construction case and the quality standard of steel bridge surface construction mixture and the inspection requirement of SMA construction quality are given in order to provide some reference for similar projects.
\end{abstract}

\section{Introduction}

With the progress and development of bridge industry in our country, the application of orthotropic steel bridge deck in long-span bridges is becoming more and more common $^{[1]}$. Laying a multi-layered protective layer structure on the orthotropic steel bridge deck can not only protect the steel bridge deck, but also increase the service life of the bridge. It also provides support and guarantee for the safety and comfort of the bridge. In addition, it effectively reduces vibration and noise caused by driving. Compared with the road deck, the complexity of stress and deformation of the steel deck pavement layer is relatively high, which must not only play a good performance in the aspects of strength, temperature stability, crack resistance and fatigue resistance, but also need to have the ability to follow the deformation of the steel plate according to the actual requirements ${ }^{[2]}$.

For the steel deck paving technology, scholars at home and abroad have also done a lot of research. Yao, $\mathrm{B}^{[3]}$ deduces the shear strength between the steel bridge deck and the epoxy asphalt pavement interface by means of experimental research and theoretical analysis, and its relation with temperature is given. The steel-UHDC composite bridge deck paving scheme is proposed, which is mainly composed of steel bridge panel, reinforced UHDC layer and asphalt wear layer. the UHDC layer and steel bridge panel are connected by studs, and the surface of steel plate and UHDC layer are provided with waterproof bonding layer. This scheme has the advantages of strong crack control, low reinforcement ratio, light weight and conventional maintenance ${ }^{[4]}$. Based on the mechanism and cause analysis of pan-alkali diseases of bridge deck pavement, $\mathrm{Hu}, \mathrm{G}, \mathrm{H}^{[5]}$ puts forward the prevention and treatment measures of pan-alkali diseases of bridge deck pavement. By investigating the domestic SMA asphalt concrete deck pavement solid engineering and research trends, Chen, $\mathrm{B}^{[6]}$, compared and analyzed the influence of different SMA asphalt raw materials on the performance of concrete road, recommended more reasonable SMA asphalt concrete deck pavement material type and concrete road performance evaluation index and technical requirements. It provides scientific basis and technical guarantee for further popularizing the wide application of SMA asphalt concrete deck pavement. Combined with practical work experience, the author probes into the construction technology of steel bridge deck asphalt concrete pavement, and plans to promote the construction of steel bridge deck pavement towards the direction of standardization and normalization.

\section{COMPARISON AND ANALYSIS OF THREE KINDS OF STEEL BRIDGE DECK PAVEMENT}

In the design of steel bridge deck pavement structure, each pavement layer has its own emphasis on the performance, so as to provide support and guarantee for bridge deck traffic. In the current phase, there are three

\footnotetext{
* Corresponding author: 2018121073@ chd.edu.cn 
types of the construction structure applied to the steel bridge deck pavement, the double-layer modified SMA, pouring asphalt concrete + high elastic SMA and doublelayer epoxy asphalt concrete. The double-layer modified SMA pavement structure is usually applied in the early steel deck pavement construction activities, which has significant advantages in the aspects of anti-rutting, fatigue resistance, water resistance and so on. However, according to the actual situation, it is accompanied by cracking, pot holes, rutting and other common diseases. For the form of pouring type + SMA pavement structure, in the early stage, SBS modified asphalt is selected in SMA structure, after technical development high elastic asphalt is selected. After the paving layer is formed and put into service, it can play a better performance in the aspects of water-proof, anti-fatigue, water-stable, antisliding and durability, but also with common diseases, which is similar to the double-layer modified SMA structure.

The formed double-layer epoxy asphalt concrete pavement structure has high strength, and has good performance in fatigue resistance and corrosion resistance. Compared with conventional asphalt concrete, its Marshall stability is stronger, and its comprehensive performance is good. However, it is accompanied by defects such as bulge, cracking, pit, etc. It is rare for permanent deformation such as travel and ruts.

The pouring SMA pavement structure is neither permeable nor absorbent. At the same time, the moisture and other types of climate have little effect on this structure, and there will be no water damage to a large extent. It has good flexibility, and the performance is not sensitive when subjected to impact and bumps. The lower layer asphalt concrete not only has good waterproof and integrity, but also has obvious advantages in thermal stability, low temperature crack resistance and deformation ability. The SMA pavement not only has good durability, but also can provide good support and guarantee for the running of the vehicle. The water-proof bonding system can also show the ideal performance in the aspects of water-proof and anticorrosion, and its toughness can effectively coordinate the deformation of the steel plate. At the same time, the water-proof bonding system can provide sufficient protection for the steel plate.

\section{LOWER LAYER POURING ASPHALT CONCRETE JOINT, MAINTENANCE TREATMENT AND QUALITY STANDARD}

For transverse joints, support the templet in advance in the position where the cross seam is to be left, ensure that the templet is the same as the spread width, and support the end templet in the front position of the cross seam, slightly larger than the spread width. When the spreading equipment walks to the position about $10 \mathrm{~m}$ from the formwork, according to the actual situation, the spreading speed should be controlled, the material placed before finishing the paving should be maximized, and then the discharging frequency should be increased, but each time the discharge quantity should be reduced, to the transverse seam, the spreading equipment should take the remaining material to smooth over the joint, lift the machine on the end template and clean up the remaining material. Then the mixture at the cross seam is clapped and leveled manually to ensure the compactness between the material and the formwork seam. For transverse joints, flat joints are usually adopted. Through cutting machine processing to form a neat new section, and after the new paving position overlap after spreading, ironing and rolling leveling.

During the spreading of the longitudinal joint, the manual pating and leveling of the formwork position are checked by the special person to ensure that the joint position after the completion of the mold removal remains full, dense and free from segregation. For longitudinal fractures, heat treatment is preferred. Before the longitudinal joint construction process begins, the original cold joint is heated by the spray gun, if the infrared heating equipment is its own, then the joint surface of the paved layer should be heated first to form a whole with the newly paved layer.

The pouring asphalt concrete pavement and the carriageway lap place should push the material to the outside neatly flatly, prevents the water seepage through the tamping leveling. The facilities used in the highway bridge, that is, the location of the contact between the fixed base and the paving part required for the lower part of the sign, guardrail, isolation belt, monitoring and so on, shall be laid the sealing belt according to the waterproof requirements.

After the completion of the operation, immediately block the scene, strictly control the entry of equipment and personnel. Measures should also be taken to prevent debris and rain erosion. Small vehicles are not allowed to pass until 72 hours pass the test. The following table 1 is the construction quality inspection and evaluation standard for building asphalt mixture pavement.

Table 1. Construction quality inspection and evaluation standard of pouring asphalt mixture pavement

\begin{tabular}{|c|c|c|c|}
\hline Project & $\begin{array}{l}\text { Frequency of } \\
\text { inspection }\end{array}$ & $\begin{array}{c}\text { Quality } \\
\text { requirement }\end{array}$ & $\begin{array}{c}\text { Experimenta } \\
\text { I method }\end{array}$ \\
\hline $\begin{array}{l}\text { Discharge } \\
\text { temperature }\end{array}$ & Per car & $190 \sim 210^{\circ} \mathrm{C}$ & $\begin{array}{c}\text { Infrared } \\
\text { thermometer }\end{array}$ \\
\hline $\begin{array}{l}\text { Mixing } \\
\text { quality }\end{array}$ & Per car & $\begin{array}{c}\text { There are no } \\
\text { white materials, } \\
\text { agglomeration, } \\
\text { segregation and } \\
\text { other } \\
\text { phenomena }\end{array}$ & Visualization \\
\hline $\begin{array}{l}\text { Liu El } \\
\text { Mobility }\end{array}$ & Per car & $10 \sim 60 \mathrm{~s}$ & Flow Test \\
\hline Penetration & $\begin{array}{l}6 \text { specimens } \\
\text { per } 200 t\end{array}$ & $1 \sim 4 \min$ & $\begin{array}{c}\text { Penetration } \\
\text { test }\end{array}$ \\
\hline Surface & At any time & $\begin{array}{l}\text { The surface is } \\
\text { flat and dense, } \\
\text { and there are no } \\
\text { wheel tracks, } \\
\text { and pushing, } \\
\text { etc. }\end{array}$ & Visualization \\
\hline
\end{tabular}




\section{LOWER LAYER POURING ASPHALT CONCRETE JOINT, MAINTENANCE TREATMENT AND QUALITY STANDARD}

This paper focuses on the construction of top layer SMA asphalt concrete pavement, and makes a detailed analysis for it. First of all, the bonding produced by asphalt slurry as the primary factor affecting the strength of SMA mixture, the quality of raw materials will have a direct impact on the quality of the mixture, so based on the comprehensive investigation of a bridge SMA pavement, combined with the local actual situation, the use of basalt aggregate and diabase aggregate, through mechanical crushing to increase the contact area of stone, with modified asphalt (this asphalt is widely used and popularized in the construction of bridge deck pavement in our country), the fiber is the same as the main line construction additive.

\subsection{Mixing of SMA mixture}

Strictly control mixing temperature and discharging temperature. The construction temperature range is shown in the table 2 .

Table 2. Construction temperature of SMA asphalt mixture of upper layer

\begin{tabular}{|c|c|}
\hline Stage & Temperature $\left({ }^{\circ} \mathbf{C}\right)$ \\
\hline Asphalt heating temperature & $165 \sim 175$ \\
\hline Aggregate temperature & $200 \sim 240$ \\
\hline Mixing factory temperature & $170 \sim 190$ \\
\hline To site temperature & $165 \sim 180$ \\
\hline Spread temperature & $\geq 160$ \\
\hline Initial pressure temperature & $\geq 155$ \\
\hline $\begin{array}{c}\text { Lowest pressure } \\
\text { temperature }\end{array}$ & $\geq 130$ \\
\hline Finished rolling temperature & $\geq 110$ \\
\hline
\end{tabular}

Test the material and mixing temperature by disk, check the matching ratio by analyzing how much material is used.

The mixing time is determined by the test in the field, and the asphalt material can be covered with all kinds of aggregate.

Arrange the special person to closely monitor the mixing uniformity during the mixing process, and find out the abnormal and timely handling. Through the advance training, master the operation essentials.

Strictly mix according to established gradation and proportion. Daily sampling analysis, check, after the end of the mixing process, should be timely discharge, the specific time to the asphalt drop flow status is appropriate.

\subsection{Transport of SMA mixtures}

The instruments for measuring temperature need to be checked regularly to avoid large errors in the detection process. In the process of use, focus on monitoring the discharge temperature and pavement temperature.

Storage and transportation vehicle loading, through their own forward and backward stacking, to avoid the situation of separation of aggregates.

Compared with the mixing capacity and spreading capacity, the vehicle transport capacity should be larger, so as to ensure that the paving equipment can carry out paving activities in a continuous and even way.

From the discharge to the paving, should be covered with tarpaulins, so as to play the role of insulation and anti-pollution.

The storage and transportation vehicle goes backwards to the front of the paver, relying on it to push forward and work together.

\subsection{Spread of the mixture}

Before carrying out the spreading construction process, the working surface should be properly handled, mainly to make clear the moisture, oil, sundries and dust on the surface of the pouring asphalt layer, and then to use the hot blower to ensure the dryness of the working surface.

The inspection group sets out the mileage pile and marks it at the barrier before spreading. The marking is forbidden to use paint and marker, and the sticker is used uniformly.

The temperature of the ironing plate of the spreading equipment should be controlled for $0.5 \mathrm{~h}$ before the formal start of the spreading operation, usually above $100^{\circ} \mathrm{C}$, and the ironing plate should always be heated during the formal spreading process.

Before starting the spreading, we should not only keep the pre-arch of the ironing plate of the spreading equipment in a reasonable range according to the actual situation, but also check the smoothness of the splicing of the ironing plate. In the process of carrying out spreading activities, special staff should be arranged to check the spreading thickness, and ensure the frequency and adjust the spreading thickness in time. In spreading machinery operation, should maintain a smooth, continuous march, until the completion of the operation before stopping rest.

The actual walking speed of the spreading equipment should be combined with the mixing and transportation capacity to ensure the matching degree of the two according to the actual situation, usually about $1-2 \mathrm{~m} / \mathrm{min}$. In the course of spreading process, we should ensure the parallelism of the crawler position on both sides of the spreading equipment.

After spreading operation has not been compacted area, no personnel and unrelated machinery in and out.

The spreading operation should be arranged in the high temperature period and work is strictly prohibited if the temperature is not up to the lower limit the temperature. 


\subsection{Compaction of SMA mixture}

This project is a steel deck pavement, so the double steel wheel roller static pressure way to carry out high-elastic SMA initial pressure process, double steel wheel oscillating roller compaction way to carry out the repressure;

The type selection, running speed and rolling times of the press can be determined by field pressure test.

In the rolling operation, select the same kind of machinery and rank, each machine should run evenly and smoothly. SMA rolling scheme is shown in Table 3;

Table 3. Rolling speed of roller

\begin{tabular}{|c|c|c|c|}
\hline $\begin{array}{c}\text { Type of roller } \\
\text { equipment }\end{array}$ & $\begin{array}{c}\text { Initial } \\
\text { pressure }\end{array}$ & Repressing & $\begin{array}{c}\text { Final } \\
\text { pressure }\end{array}$ \\
\hline $\begin{array}{c}\text { Static steel } \\
\text { wheel }\end{array}$ & $2 \sim 3$ & & $2.5 \sim 5$ \\
\hline Generation & & $4 \sim 5$ & \\
\hline
\end{tabular}

After spreading operation, should carry on the centralized compaction immediately, in order to reach the target compaction degree as soon as possible;

To prevent mechanical bonding, spray a little atomized water on the wheel if necessary.

Small vehicles are allowed to pass 24 hours after rolling operations.

\subsection{Treatment of construction joints}

The transverse joint is basically the same as the lower layer pouring type. for the transverse joint, the flat joint is usually adopted. Through cutting machine processing to form a neat new section, and after the new paving position overlap after spreading, ironing and rolling leveling.

Longitudinal joint spreading by a special person to check the formwork manual pat solid, smooth situation, to ensure that the joint after demoulding full, dense, no segregation. For longitudinal fractures, heat treatment is preferred. Before the longitudinal joint construction, the original cold joint is heated with a spray gun in advance, and the joint surface of the paved layer should be heated to form a whole with the newly paved pavement when it comes with its own infrared heating equipment.

\subsection{Inspection method of construction quality}

The following table 4 is the inspection requirements for the construction quality of modified asphalt SMA.

Table 4. Construction quality inspection requirements of modified asphalt SMA

\begin{tabular}{|c|c|c|c|}
\hline Project & $\begin{array}{c}\text { Frequency of } \\
\text { inspection }\end{array}$ & $\begin{array}{c}\text { Quality } \\
\text { requirement }\end{array}$ & $\begin{array}{c}\text { Experimenta } \\
\text { I method }\end{array}$ \\
\hline Surface & At any time & $\begin{array}{c}\text { No oil spots, } \\
\text { tracks or } \\
\text { segregation, } \\
\text { etc. }\end{array}$ & Visualization \\
\hline Seam & At any time & $\begin{array}{c}\text { Flat, tight and } \\
\text { straight }\end{array}$ & $\begin{array}{c}\text { Visual, 3- } \\
\text { meter ruler }\end{array}$ \\
\hline
\end{tabular}

\begin{tabular}{|c|c|c|c|}
\hline $\begin{array}{l}\text { Construction } \\
\text { temperature }\end{array}$ & $\begin{array}{l}\text { One vehicle } \\
\text { per turn }\end{array}$ & No Jumper & $\begin{array}{c}\text { Digital } \\
\text { display } \\
\text { thermometers }\end{array}$ \\
\hline $\begin{array}{l}\text { Asphalt } \\
\text { content }\end{array}$ & $\begin{array}{c}\text { Once per } \\
\text { equipment per } \\
\text { day } \\
\end{array}$ & $-0.1,+0.2$ & $\begin{array}{l}\text { Sampling and } \\
\text { centrifugation } \\
\text { sampling } \\
\end{array}$ \\
\hline $\begin{array}{l}\text { Marshall's } \\
\text { test }\end{array}$ & $\begin{array}{c}\text { Twice per } \\
\text { equipment per } \\
\text { day }\end{array}$ & $\begin{array}{l}\text { Meet design } \\
\text { requirements }\end{array}$ & $\begin{array}{l}\text { Sampling } \\
\text { molding test }\end{array}$ \\
\hline $\begin{array}{l}\text { Wheel } \\
\text { rutting test }\end{array}$ & At a pinch & $\begin{array}{l}\text { Meet design } \\
\text { requirements }\end{array}$ & $\begin{array}{c}\text { Sampling } \\
\text { molding test }\end{array}$ \\
\hline $\begin{array}{c}\text { Permeability } \\
\text { test }\end{array}$ & At any time & $\begin{array}{l}\text { Basically no } \\
\text { water seepage }\end{array}$ & $\begin{array}{c}\text { Water } \\
\text { pouring for } \\
\text { observation }\end{array}$ \\
\hline Compactness & $\begin{array}{l}\text { Single } 10 \text { per } \\
\text { kilometre }\end{array}$ & $\begin{array}{l}\text { Meet the } \\
\text { theoretical } \\
\text { density } \\
\text { compaction }\end{array}$ & \multirow[t]{2}{*}{$\begin{array}{l}\text { Drilling } \\
\text { method }\end{array}$} \\
\hline $\begin{array}{c}\text { Surface } \\
\text { voids }\end{array}$ & $\begin{array}{l}\text { Single } 10 \text { per } \\
\text { kilometre }\end{array}$ & $3.5 \sim 6$ & \\
\hline Planeness & $\begin{array}{c}\text { Daily } \\
\text { pavement } \\
\text { determination } \\
\text { of road } \\
\text { sections in a } \\
\text { continuous } \\
\text { manner }\end{array}$ & $\begin{array}{l}\text { Lower than } \\
\text { design } \\
\text { requirements }\end{array}$ & $\begin{array}{c}3 \mathrm{~m} \\
\text { continuous } \\
\text { flatness } \\
\text { Instrument }\end{array}$ \\
\hline $\begin{array}{c}\text { Friction } \\
\text { coefficient } \\
\text { Structural } \\
\text { depth }\end{array}$ & $\begin{array}{l}200 \mathrm{~m} \\
\text { everywhere }\end{array}$ & $\begin{array}{l}\text { Comply with } \\
\text { design } \\
\text { requirements }\end{array}$ & $\begin{array}{l}\text { Pendulum } \\
\text { sand laying }\end{array}$ \\
\hline
\end{tabular}

\section{Conclusion}

To sum up, in view of a large number of engineering experience, in view of the design and application of a bridge in the form of " lower cast asphalt concrete top layer epoxy asphalt concrete ", considering the advantages of superior deformation chasing and excellent strength and high temperature stability of epoxy asphalt concrete, the author puts forward higher requirements for the construction technology and construction technology of steel deck pavement. According to the actual situation, the resulting surface cracks should be timely and properly treated, that is, the use of asphalt joint closure. For the surface pit disease, the damaged structures are excavated and then filled with conventional asphalt mixture. With the continuous increase of service life, if the whole surface layer is seriously damaged, the more ideal maintenance effect can be realized only by milling and re-laying the SMA surface layer, so that the actual maintenance cost can be effectively controlled.

\section{References}

1. Zhang, Q. H., Yi-Zhi, B. U., \& Qiao, L. I.. (2017). Review on fatigue problems of orthotropic steel bridge deck. China Journal of Highway \& Transport, 30(3), 14-30 and 39.

2. Pfeil, M. S., Battista, R. C., \& Mergulhao, A. J. R.. (2005). Stress concentration in steel bridge orthotropic decks. Journal of Constructional Steel Research, 61(8), 1172-1184.

3. Yao, B., Zhang, Y. Y. , \& Fang-Chao, L. I. . (2017). Shear characteristics of interface between steel 
bridge deck and epoxy asphalt pavement. China Journal of Highway \& Transport, 30(3), 132-138.

4. Liu, H, Y., Li, L., and Li, H, D. (2019). Analysis and fatigue test on structural mechanical properties of steel-UHP composite concrete bridge deck, Highway Traffic Technology.

5. Hu, G, H et al. (2019). Study on Pan-alkali mechanism and prevention measures of asphalt concrete deck pavement, Highway.

6. Chen, B et al. (2019). Application and research progress of SMA asphalt concrete deck pavement materials. Road Building Machinery and Construction Mechanization, 35-40. 